\title{
Disaster Risk Analysis to Support the Development of Regional Spatial Plan of Tasikmalaya Regency, Indonesia
}

\author{
Wiwin Winarti \\ Agency for Regional Disaster Management, Tasikmalaya, INDONESIA \\ wiwinwinarti.tsk@gmail.com
}

\begin{abstract}
Tasikmalaya Regency is one of the regencies on the West Java Province that is vulnerable to disaster and currently in the second position at national level. Based on data from BPBD (Regional Disaster Management Agency) of Tasikmalaya Regency, from January to June 2016, total disaster was 243 events and 64\% landslide disaster, with total loss of IDR 19.5 billion. Therefore, multi-disaster risk mapping is necessary, as a form of mitigation effort. This multi-disaster mapping was arranged with steps as follows: analysis and mapping of vulnerability or susceptibility, capacity and risk of each disaster, based with Geographic Information System (GIS) with Arc Map 10.3 software, then being combined (overlay). The susceptibility and capacity levels used the parameters as according to Regulation of Chief of BNPB (Badan Nasional Penanggulangan Bencana - Indonesian National Board for Disaster Management) No. 02 Year 2012, which are: social susceptibility, economy susceptibility, physical susceptibility and environmental susceptibility. Study of landslide, flood, and earthquake disasters risks were classified according to BNPB Chief Regulation No. 02 Year 2012 into 3 (three) multi-disaster risk classes with Natural Breaks (Jenks) method, which resulted into: low risk class $(57.01 \%)$, medium risk class $(35.08 \%)$, and high risk class $(7.92 \%)$. Based on the study, it is known that the region with classification of high risk to disaster needed to be rearranged in the spatial pattern planning, as a revision material for the Land Use Plan (Rencana Tata Ruang Wilayah - RTRW) of Tasikmalaya Regency in 2011-2031.
\end{abstract}

Keyword: Susceptibility; capacity; risk; spatial plan; geographic information system

\section{INTRODUCTION}

The Tasikmalaya Regency is one of regencies on the West Java Province that is vulnerable to disaster and currently in the fifth position at national level (Badan Nasional Penanggulangan Bencana (BNPB), 2012). Based on data from disaster report of BPBD (Badan Penanggulangan Bencana Daerah - Regional Disaster Management Agency) in Tasikmalaya Regency, during the year 2013 - 2016, there have been 1.254 events. Based on 2016 disaster data period of January to June 2016, there have been 162 events with details as follows: 121 landslide event (74.69\%), others 18 event (11.11\%), 10 strong wind event $(6.17 \%), 9$ fire incident $(5.56 \%)$, and 4 flood event $(2.47 \%)$. The highest intensity of disaster events occurred in 2014, in which there were 222 landslide disasters.

The disaster that occurred in 2016 impacted 795 families and 2.844 people; 3 houses destroyed, 56 houses were heavily damaged, moderate damages on 44 houses, 63 houses suffered minor damage, 122 houses were threatened, and 738 houses were affected; total estimated loss was Rp. 12,019,790,000. The biggest losses come from damages of houses, roadway, and the potential crop failures due to the ricefield or plantation affected by the landslide, flooding, and earthquake. Therefore, the multi-disaster risk mapping is needed as the mitigation effort in Tasikmalaya
Regency. Tasikmalaya Regency is geographically located between $7^{\circ} 02^{\prime} 29^{\prime \prime}$ - 7०49'08"S and 107 ${ }^{\circ} 54^{\prime} 10^{\prime \prime}$ $108^{\circ} 26^{\prime} 42^{\prime \prime E}$. Area of the Tasikmalaya Regency is approximately 270.881 hectares which is divided into 39 sub-districts (see Figure 1).

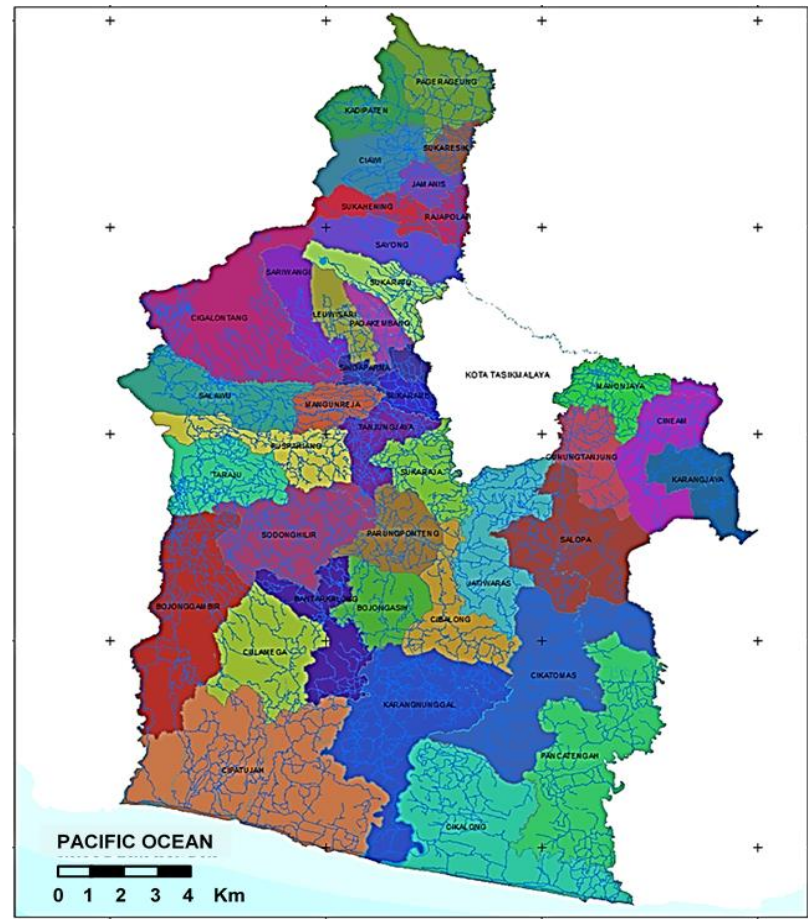

Figure 1. Map of Tasikmalaya administration boundary 
The hydrology condition in Tasikmalaya Regency is divided into 2 parts which are the surface water and ground water. Surface water consists of river area, lakes and irrigation network; while ground water consists of water springs. The river area in Tasikmalaya Regency consists of large and small river stream area, and is a part of drainage system which influenced by its topography condition and physiography structure. Tasikmalaya Regency has 6 large or main river stream areas, which are the Cilangla River, Cimedang, Cisanggiri, Cipatujah, Citanduy and Ciwulan River. The river flow pattern is generally radial, for it is more affected by the volcanic dominance.

\section{METHOD OF APPROACH}

Based on BNPB (Badan Nasional Penanggulangan Bencana - Indonesian National Board for Disaster Management) Chief Regulation No. 02 Year 2012 (Badan Nasional Penanggulangan Bencana (BNPB), 2012), the disaster risk study components consist of threat, susceptibility, and capacity. These components are used to obtain disaster risk of a certain area by calculating the potency of exposed lives, property loss, and environmental damage. Disaster risk is directly proportional with accumulation of hazard and susceptibility, and inversely proportional with capacity.

\subsection{Risk Map Concept}

Disaster risk level could be assessed based on the size of threat level and susceptibility on a particular region. Disaster risk analysis could be conducted based on the Geographic Information System (GIS). Disaster risk mapping could be applied in Geographic Information System (GIS) which could be spatially displayed and generated susceptibility map, susceptibility map, capacity map, and disaster risk map.

\subsection{Multi-disaster Risk Mapping}

Multi-disaster map is a map that depicts risk of several disasters in a single map format. The multi-disaster map could describe landslide-prone, flood-prone, and earthquake-prone areas all in single map format, therefore it could be known which area is at risk of being exposed to several hazards all at once. The common basic formula for risk analysis that was suggested in the 'Disaster Risk Mitigation Planning Guide' (Pedoman Perencanaan Mitigasi Risiko Bencana) prepared by the Indonesian National Board for Disaster Management (Badan Nasional Penanggulangan Bencana Indonesia - BNPB) in the Chief of BNPB Local Regulation No.4 Year 2008, is as follows:
Risk $=\frac{H \times V}{C}$

where Risk is Disaster Risk, $H$ is hazard or threat of a certain disaster that tends to occur with certain intensity in certain location, $V$ is susceptibility expected loss (impact) in a certain area in a case where certain disaster occurs with certain intensity, $C$ is an adaptive capacity (capacity available in the area to recover from certain disaster). The $V$ is usually defined as exposure (population, asset, etc.) that depend on the sensitivity for specific intensity of disaster.

\subsection{Geographic Information System}

GIS is a computer-based information system that combines map element (geographic) and attributes of information data that is designed to process, manipulate, analyze, demonstrate and display spatial data for planning, data processing, and research of related field. The Geographic Information System (GIS) is a system that captures, checks, integrates, manipulates, analyses, and displays data that spatially referred to the earth condition. The GIS technology integrates database general operations, such as query and statistical analysis, with a unique visualization and analysis ability that the mapping possessed. This approach was used to show relation between threat, susceptibility, and capacity performing disaster risk level. Based on the approach, it could be seen that the disaster risk level depends on:

a) Susceptibility level of the area

b) Susceptibility level of the threatened area

c) Capacity level of the threatened area

The mapping analysis of GIS layer combination based on the vector and grid that were being used, with saved data that used vector structure, and the resulted index was in grid format. For the map of susceptibility and capacity, map was vastly made based on available data and information, in form of social, economy, physical, environmental, and capacity data.

\subsection{Susceptibility Analysis}

Susceptibility is a product of social, economy, physical, and environmental susceptibility with weighting factor according to threat type (BNPB, 2012). Susceptibility index parameter is shown in the following equations,

$$
\begin{aligned}
& L S=0.4 S+0.25 E c+0.25 P+0.1 E n \\
& F S=0.4 S+0.25 E c+0.25 P+0.1 E n \\
& E S=0.4 S+0.3 E c+0.3 P
\end{aligned}
$$


where $L S, F S$, and $E S$ are defined as the susceptibility level toward landslide, flood, and earthquake, respectively, while $S$ denotes social susceptibility score, $E c$ is economy susceptibility score, $P$ is physical susceptibility score, and $E n$ is environmental susceptibility score.

\subsection{Capacity Mapping Analysis}

Capacity is a dynamic and most feasible component to be managed in order to reduce disaster risk. Capacity index is divided into three levels, which are low, medium and high.

The capacity index parameter is shown as follows:

$$
C I=0.1 D M I+0.1 E W+0.2 D E+0.3 D R F+0.3 A B(5)
$$

where $C I$ is capacity index parameter, $D M I$ is disaster management institutional score, $E W$ is early warning and disaster risk study score, $D E$ is disaster education score, $D R F$ is disaster risk factor reduction, and $A B$ is awareness building score.

\subsection{Risk Mapping Analysis}

Disaster risk could be discovered from the relation between disaster threat, susceptibility, and capacity. Disaster risk was derived from formulation result of total score for threat susceptibility and capacity by using the Equation 1. Disaster risk mapping was conducted by combining the threat map, susceptibility map and capacity map.

\section{RESULTS OF ANALYSIS}

\subsection{Susceptibility}

\subsubsection{Landslides Susceptibility}

The parameter that caused landslide susceptibility in this research consisted of seven parameters which were the secondary data as follows: slope map, geology, soil type, land use, elevation, distance from river and rainfall. Further calculation for landslide susceptibility level was referred to Sopheap (2007). By calculating the Susceptibility Potential Index (SPI) which was calculated with equation as follows:

$$
S P I=\sum_{i=1}^{n}\left(W_{s, i} \times S_{s, i}\right)
$$

Where $W_{s i}$ is weight value of the $i$ susceptibility parameter and $S_{s i}$ is score value of $i$ susceptibility parameter.

Based on the SPI value from the above formula, the landslide susceptibility level was classified as follows. a) Low landslide susceptibility

b) Medium landslide susceptibility

c) High landslide susceptibility

Landslide susceptibility map was obtained from overlay process of the landslide susceptibility causal parameters. after each parameter were given weight that showed effect of each parameter to landslide susceptibility and the score that showed level of sensitivity of a certain class in a certain parameter (see Figure 4). Based on the score and weight of each parameter, the landslide susceptibility is then classified into classes, i.e. the low susceptibility class $(18.86 \%)$. medium susceptibility class $(45.44 \%)$ and high susceptibility (35.70\%), see Figure 2.

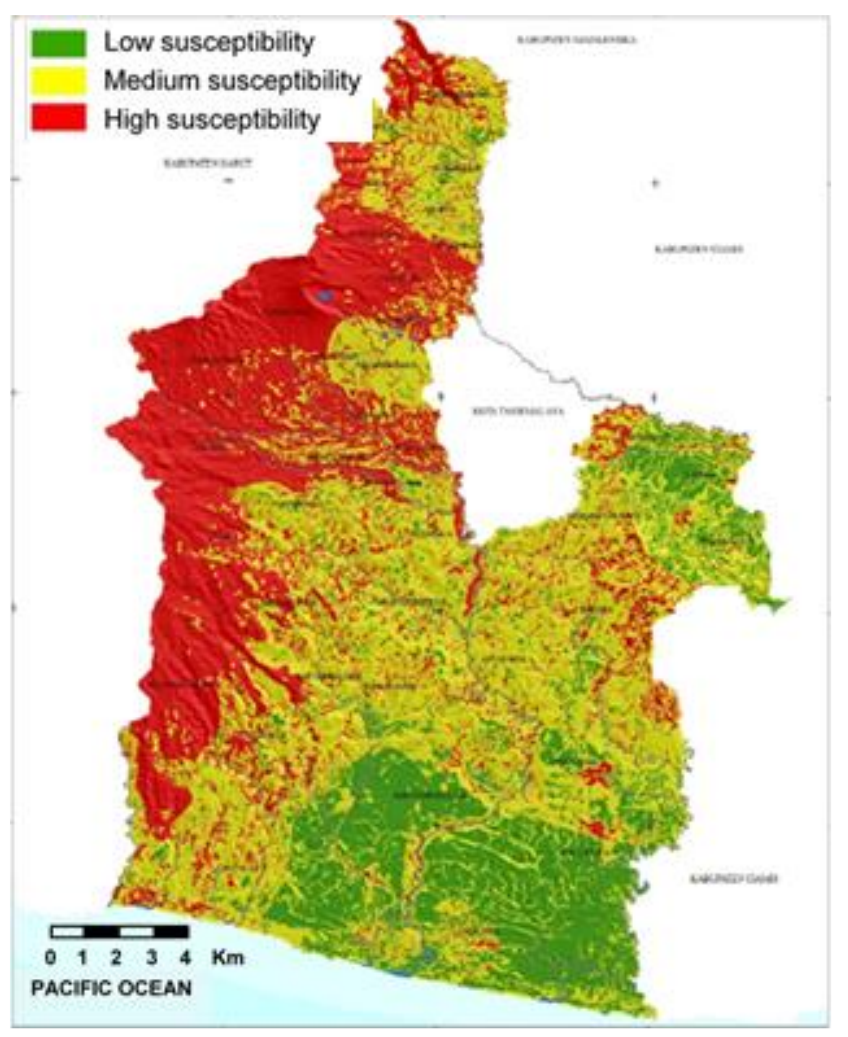

Figure 2. Map of landslide susceptibility

Based on the landslide susceptibility map in the Tasikmalaya Regency (Figure 2), it is seen that subdistricts that have low susceptibility were generally spread over the area with slope of $<5^{\circ}$ and $5^{\circ}-15^{\circ}$ with elevation of $0-500 \mathrm{~m}$ asl. Several sub-districts that included in low susceptibility class were dominantly in several sub-districts at the south part of Tasikmalaya Regency (Cikalong, Pancatengah, Karangnunggal, Cipatujah, and Bojongasih Sub-district) and at the north part of Tasikmalaya Regency with slope of $<5^{\circ}$ and elevation of 0-500 m asl (Sukaresik, Rajapolah, Padakembang, and Jamanis Sub-district). The area with highest susceptibility class was dominantly spread over the sub-district of Bojonggambir, Sodonghilir, Taraju, 
Mangunreja, Salawu, Sukarame, Singaparna, Cigalontang, Sariwangi, Leuwisari, Sukaratu, Cisayong, Sukahening, Ciawi, Pagerageung and Kadipaten.

\subsubsection{Overlay and analysis of flood susceptibility potency}

The method used in this research was concentrated on the construction of flood susceptibility map in the research location by combining the susceptibility elements. After the Digital Elevation Model (DEM) processing, the most important secondary data were extracted, such as the slope map, flow direction, and flow accumulation. Along with the additional thematic information (such as geological map, land cover, etc.). From the aforementioned data processing, there are four main factors in order to construct flood susceptibility maps, such as the topographic wetness index, lithology, land cover roughness, and vegetation cover index $(N D V I)$. These factors were evaluated to generate the final map, which categorized the location into several flood susceptibility zones.

\section{a) Topographic Wetness Index (TWI)}

The factors that influence flood, and the gained information were presented next from DEM data into slope data, flow direction, flow accumulation, and the Topographic Wetness Index (TWI). This index was derived from surface variables which are formulated as follows, and the spatial result is presented in Figure 3.

$T W I=\ln (\alpha / \tan \beta)$

where $\alpha$ is flow accumulation and $\beta$ is slope.

\section{b) Permeability level parameter}

Other than topography, the important factor that affects flood runoff of a location is the lithology factor of the location. Based on the permeability, rocks are divided into three categories (Soulios, 1996).

The categories which are:

Rocks with high permeability of $\mathrm{k} \geq 10-5 \mathrm{~m} / \mathrm{s}$;

Rocks with moderate permeability of 10-5> k>10 m/s; Rocks with low permeability of $\mathrm{k} \leq 10-7 \mathrm{~m} / \mathrm{s}$.

c) Roughness Level Parameter (Land Cover)

The land cover in the research location was conducted through the CORINE LAND COVER 2000 program. Based on the roughness level (e-EcoRisk, 2004) which generated value of each roughness level in the land cover code from CORINE LAND COVER 2000.

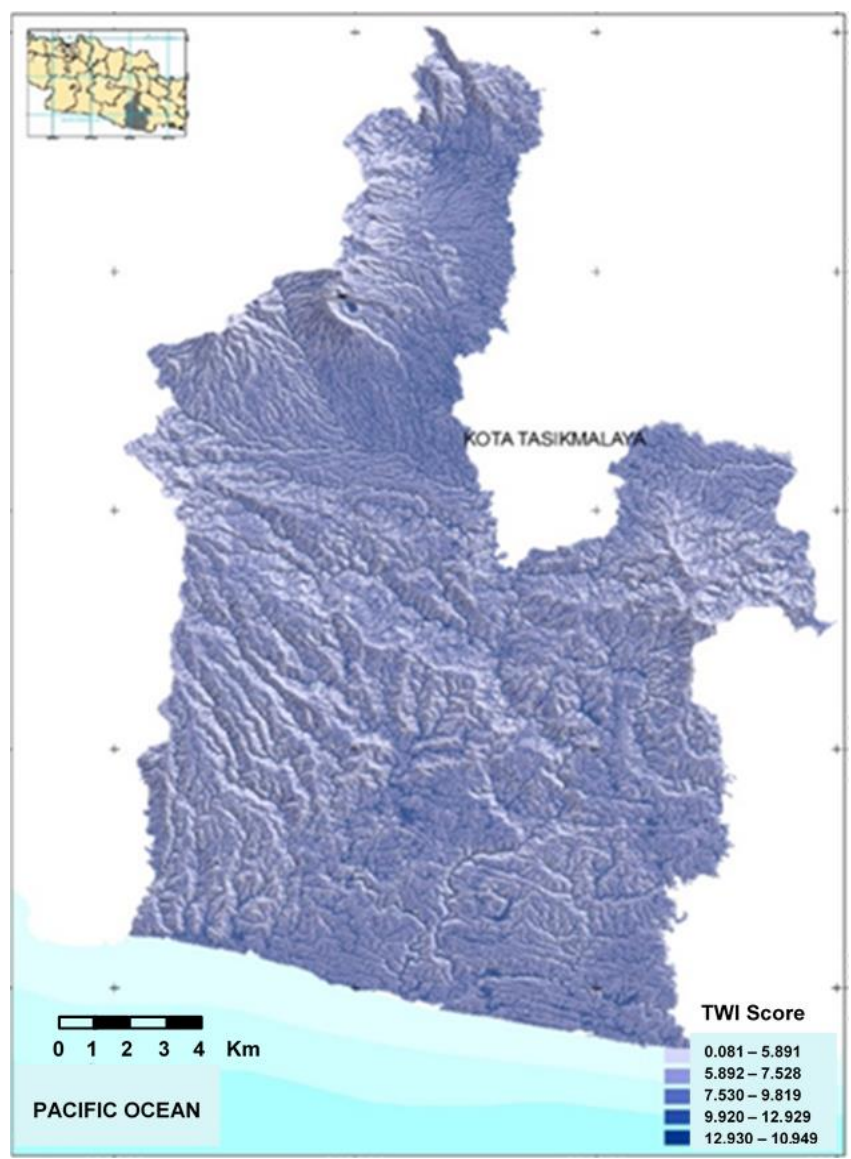

Figure 3. Map of Topographic Wetness Index (TWI)

\section{d) NDVI (Normalized Difference Vegetation Index) Parameter}

Normalized imaging or NDVI (Normalized Difference Vegetation Index) is image calculation to discover the level of greenery, which is very good as an initial beginning to divide vegetation area. The NDVI value was obtained by the near-infrared calculation with the visible light which was reflected by the vegetation (Kafira, et al., 2015).

To determine the vegetation index or also called the Normalized Difference Vegetation Index (NDVI), following equation was used (see Figure 4):

$$
\begin{aligned}
& N D V I=\frac{N I R-R}{N I R+R} \\
& N D V I=\frac{((T M+4)-(T M+3))}{((T M+4)+(T M+3))}
\end{aligned}
$$

The NDVI values were theoretically ranged from -1 to 1 , as derived from the above mathematical equations. Values above zero indicate the presence of green vegetation (chlorophyll), or soil with no vegetation (value close to zero); while values under zero indicate the absence of dense vegetation, and the presence of water, snow, ice, and cloud (Dalezios, 2002). Based on 
the overlay result of each flood disaster susceptibility parameter above mentioned, the resulted data then were classified into three flood susceptibility class, which are the low susceptibility class $(24.31 \%)$, medium susceptibility class (55.98\%), and low susceptibility $(19.71 \%)$ (see Figure 5).

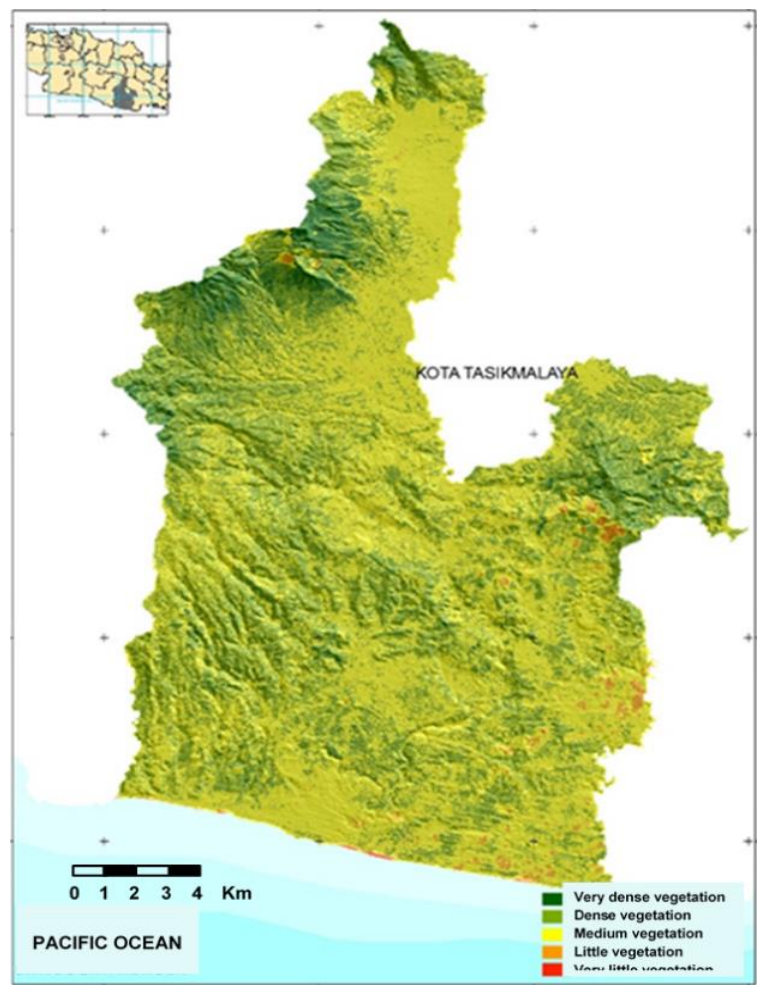

Figure 4. NDVI map

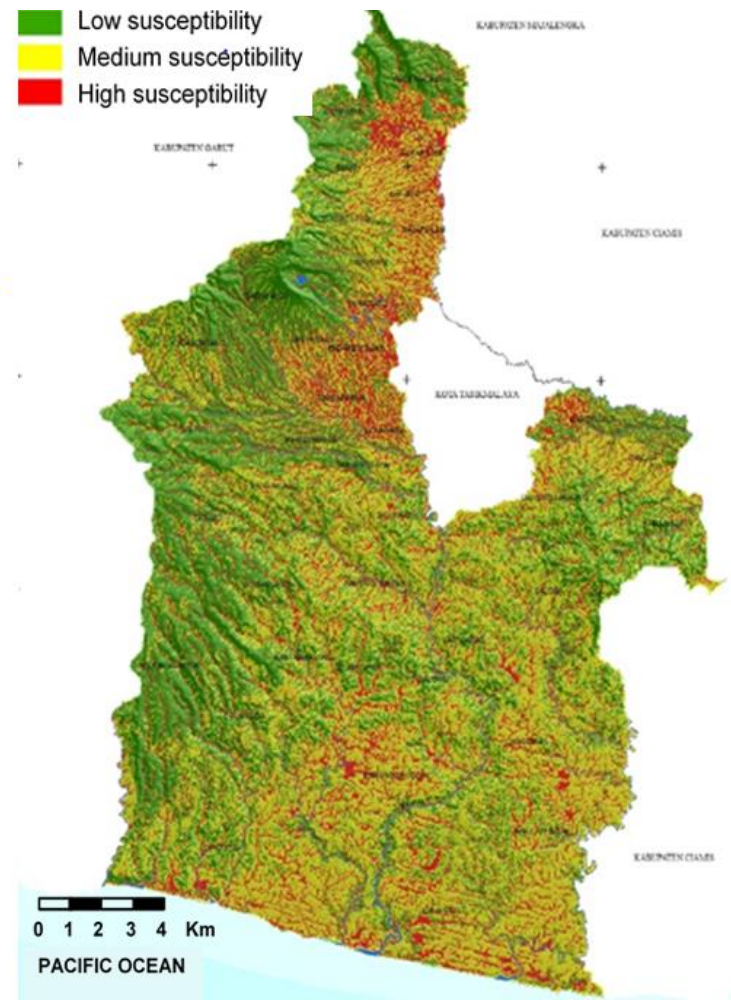

Figure 5. Map of flood susceptibility
5) Overlay and analysis of earthquake susceptibility mapping

From several studied literature which supported with the presence of data, there were 4 (four) parameters that influence the earthquake disaster, which is as follows:

a) Earthquake shock, with earthquake intensity indicator from Modified Mercalli Intensity (MMI).

b) Fracture, with indicator distance from active fault

c) Value of spectral response acceleration of 0.2 seconds (Ss) which being exceeded in 50 years

d) Geological formation

Determination of earthquake susceptibility area was referred to FEMA P-154 (2015) and Ramadhanti (2011). Determination of the indicator values was by the scoring process, with weight value condition by giving it number 1,2 , and 3 . Indicator value 1 indicated that the susceptibility level is low on every indicator, indicator value 2 is medium susceptibility level, while indicator value 3 indicated high susceptibility level. The data processing with ArcMap 10.3 software generated earthquake disaster susceptibility class which was classified into 3 (three) classes, which are: low susceptibility $(9.40 \%)$, medium susceptibility (48.84\%), and high susceptibility (41.76\%). The spatial result is presented in Figure 6.

\subsection{Susceptibility Mapping and Analysis}

The indicator being used in the susceptibility analysis was the information on exposure. Susceptibility map analysis was divided into social susceptibility, economy susceptibility, and ecology/environmental susceptibility. The susceptibility was defined as exposure times with sensitivity. The exposure 'assets' were including human life (social susceptibility), economy area, physical structure, and ecology/environmental area. Compositions of exposure were such as population density, gender ratio, poverty ratio, disable ratio, and age group ratio.

Susceptibility level was divided into two level, which was differentiated based on the parameter that became factor which affected the susceptibility level, which was the same parameters that affected the susceptibility level for landslide disaster, yet different with the earthquake disaster susceptibility level parameter. In this research, the researcher determined the parameter and weight by referring to BNPB Chief Regulation No. 02 Year 2012. The flood and landslide disaster susceptibility levels were classified with Natural Breaks (Jenks) method into 3 (three) classes as follows: low susceptibility class $40.95 \%$, medium susceptibility $41.67 \%$, and high susceptibility $17.39 \%$ (see Figure 7). 


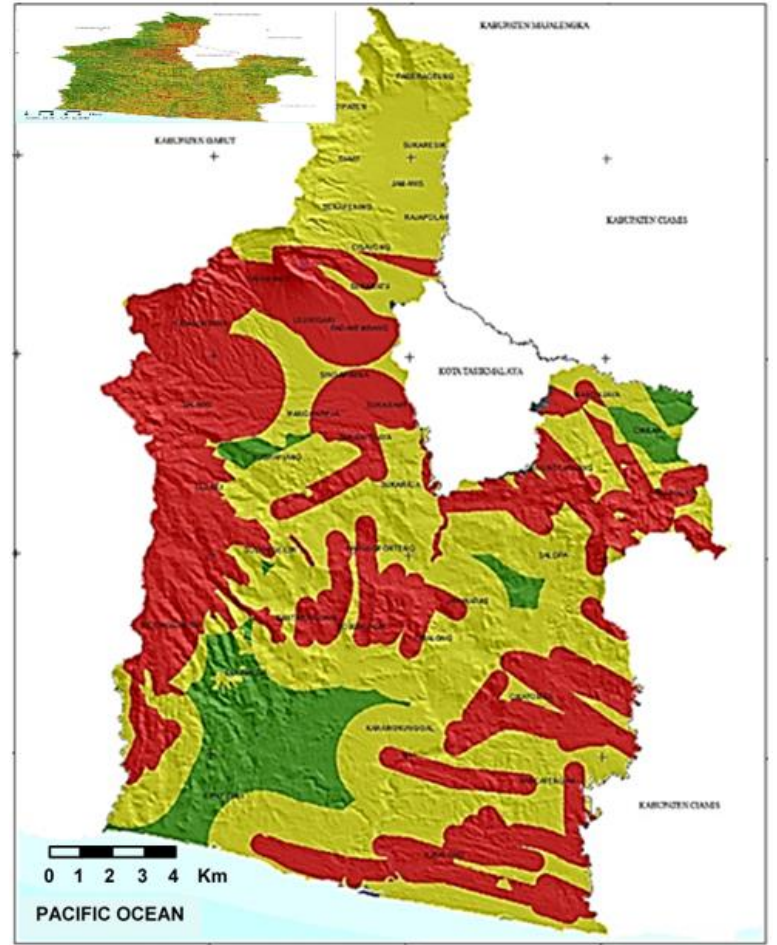

Figure 6. Map of earthquake susceptibility

The parameter of earthquake disaster susceptibility class was different with the class parameters for landslide and earthquake disasters susceptibility. Based on the data processing result from the susceptibility parameter, it was known that the susceptibility class was as follows: area with low susceptibility class was $42.66 \%$, medium susceptibility class was $42.97 \%$, and high susceptibility class was $14.39 \%$ (see Figure 8 ).

\subsection{Capacity Mapping and Analysis}

Capacity map is a map that shows the tenacity level of a certain area to disaster. Determination of capacity index was referred to BNPB Chief Regulation No. 02 Year 2012. The capacity map is prepared based on the government regulation, early warning study, disaster study, and awareness parameters. Every capacity parameter has different weight value. The more capacity type on a sub-district, the better the capacity level on that village will be. The landslide disaster capacity class that already included in medium criteria was the sub-district that already has parameters of regulation and institutional, early warning, and risk disaster study.

Capacity level for the landslide disaster in Tasikmalaya Regency was as follows: low capacity category $98.30 \%$ from the entire sub-districts in Tasikmalaya Regency, and $1.70 \%$ with medium capacity category. Several villages in the sub-district that was included in the medium criteria were: Cigalontang in Cigalontang Subdistrict, Karyabakti Village, and Parunponteng Village at Parungponteng Sub-district, Pusparahayu Village at

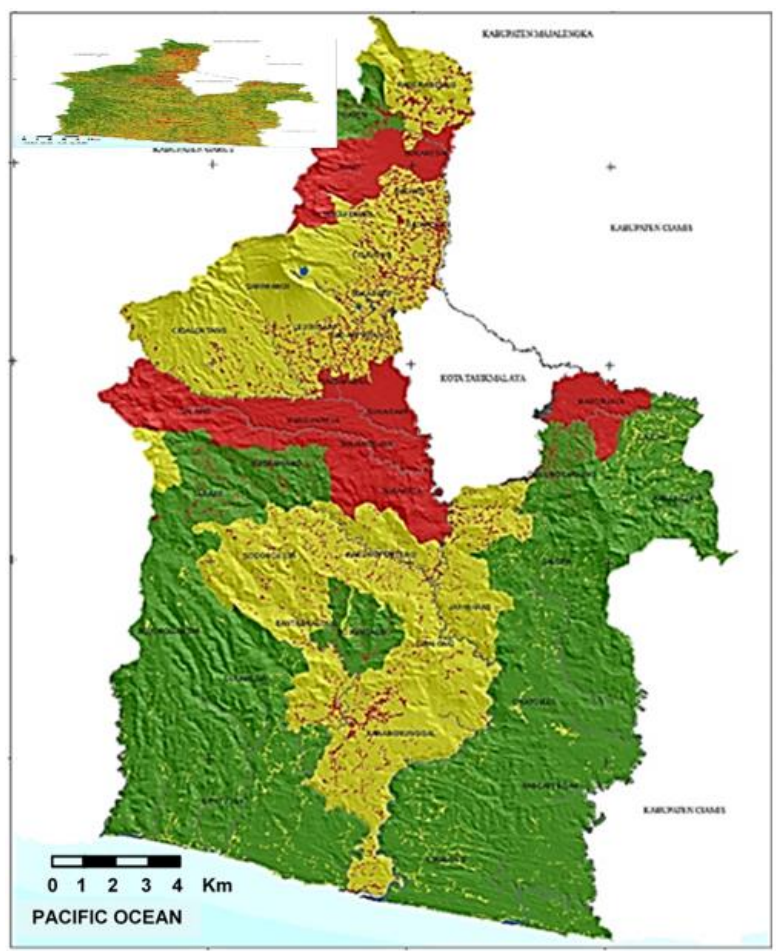

Figure 7. Map of landslide and flood susceptibility

Puspahiang Sub-district, Sukasari Village and Neglasari Village at Salawu Sub-district. More details are shown in Figure 9, which is the landslide disaster capacity map in Tasikmalaya Regency.

The landslide disaster capacity class that already included in medium criteria was the sub-district that already has parameters of regulation and institutional, early warning, and risk disaster study. Sub-districts that included in the medium capacity class criteria were: Sukaratu Sub-district and Sukaresik Sub-district.

The flood disaster capacity indexes were as follows: low capacity of $98 \%$ from the entire sub-districts in Tasikmalaya Regency, and $2 \%$ with medium capacity class category. The flood disaster capacity mapping is shown in Figure 10.

\subsection{Risk Mapping and Analysis}

The risk map was created with the Arc Map 10.3 software. The overlay process used the intersect feature, which was the Geoprocessing-Intersect. The result from intersecting process was combination map filled with attributes such as the threat score, susceptibility score, and capacity score. The data processing resulted to risk value that was classified into 3 (three) classes as follows: low risk class of $45.39 \%$, medium risk class of $38.19 \%$, and high risk class of $16.42 \%$. The sub-districts with high risk to landslide disaster are as follows: Sukaraja, Tanjungjaya, Mangunreja, Manonjaya, Salawu, Sukarame, Singaparna, Rajapolah and Ciawi. More details could 
be seen in Figure 11 which is the risk map for landslide disaster. Flood risk map was prepared by conducting overlay on threat map, susceptibility map, and capacity map. To obtain total risk score, the threat score then was multiplied with susceptibility score and was divided with capacity score. Total risk scores were classified into three classes, which are the low risk class $(58.82 \%)$, medium risk class $(33.89 \%)$, and high risk

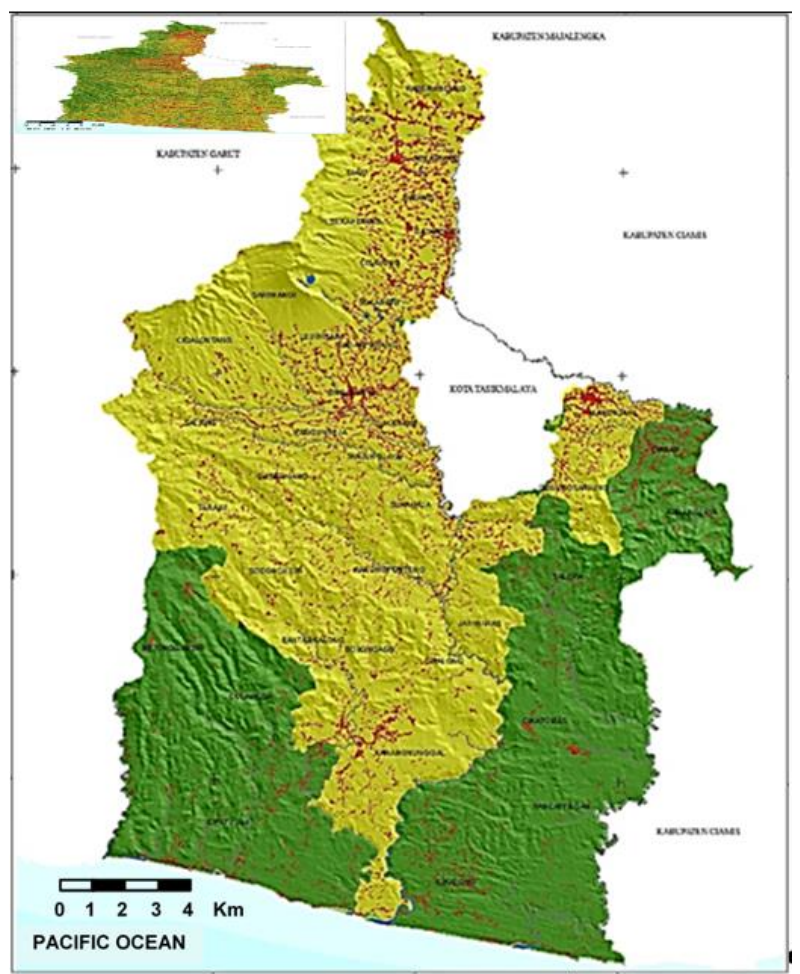

Figure 8. Map of earthquake susceptibility

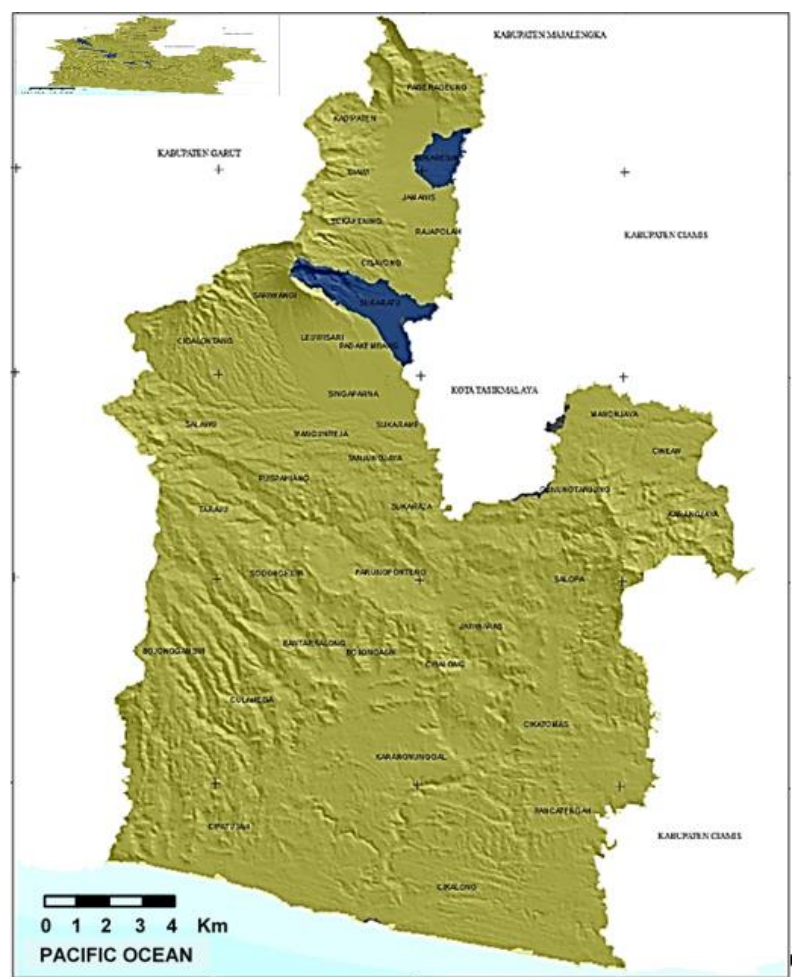

Figure 10. Map of flood capacity class (7.29\%). More details could be seen in Figure 12, which is the risk map for flood disaster. The data processing result then showed the value for earthquake disaster risk, which were classified into 3 (three) risk classes, as follows: low risk class of $78.96 \%$, medium risk class of $15.68 \%$, and high risk class of $5.37 \%$. Details could be seen in Figure 13.

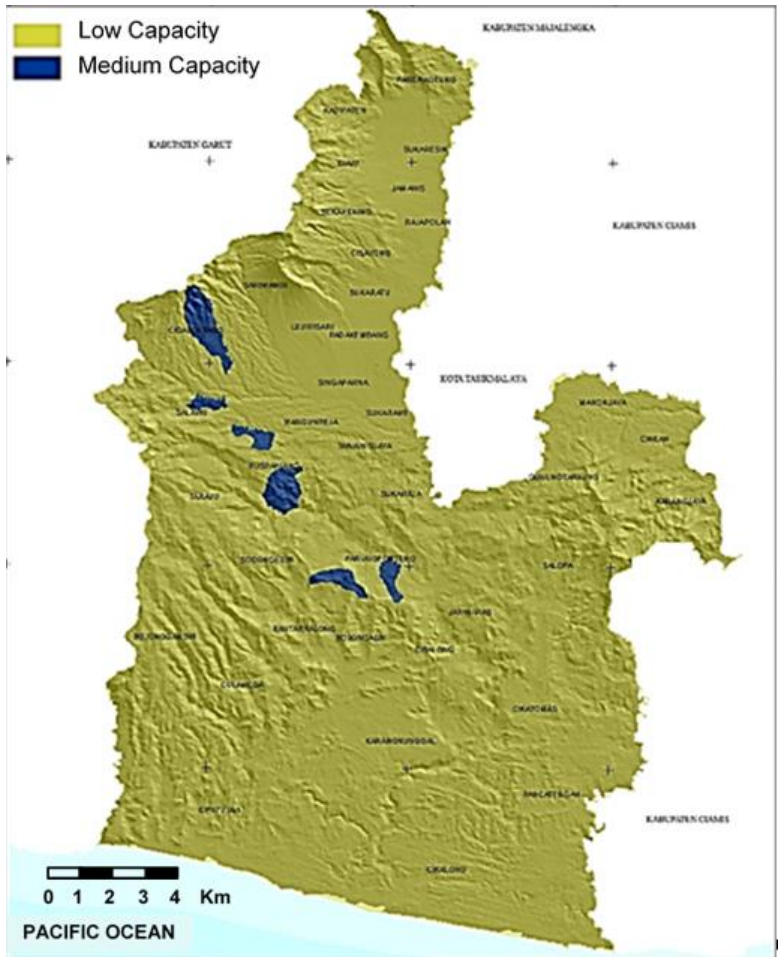

Figure 9. Map of landslide capacity

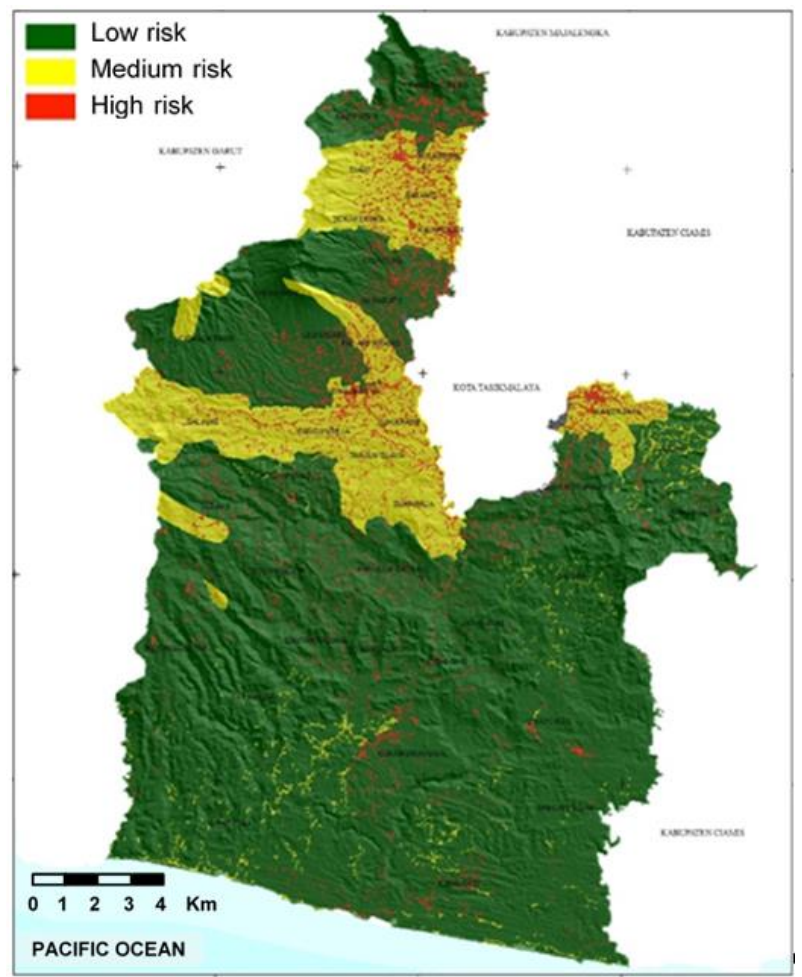

Figure 11. Map of landslide disaster risk 


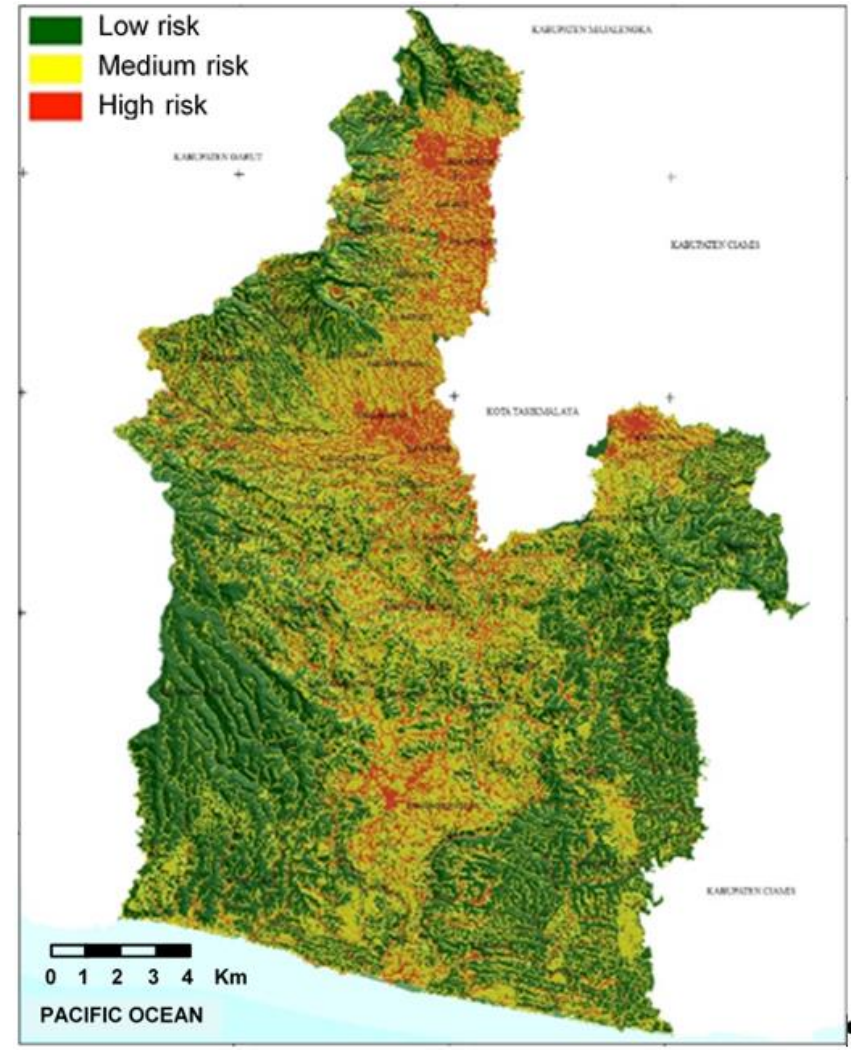

Figure 12. Map of flood disaster risk

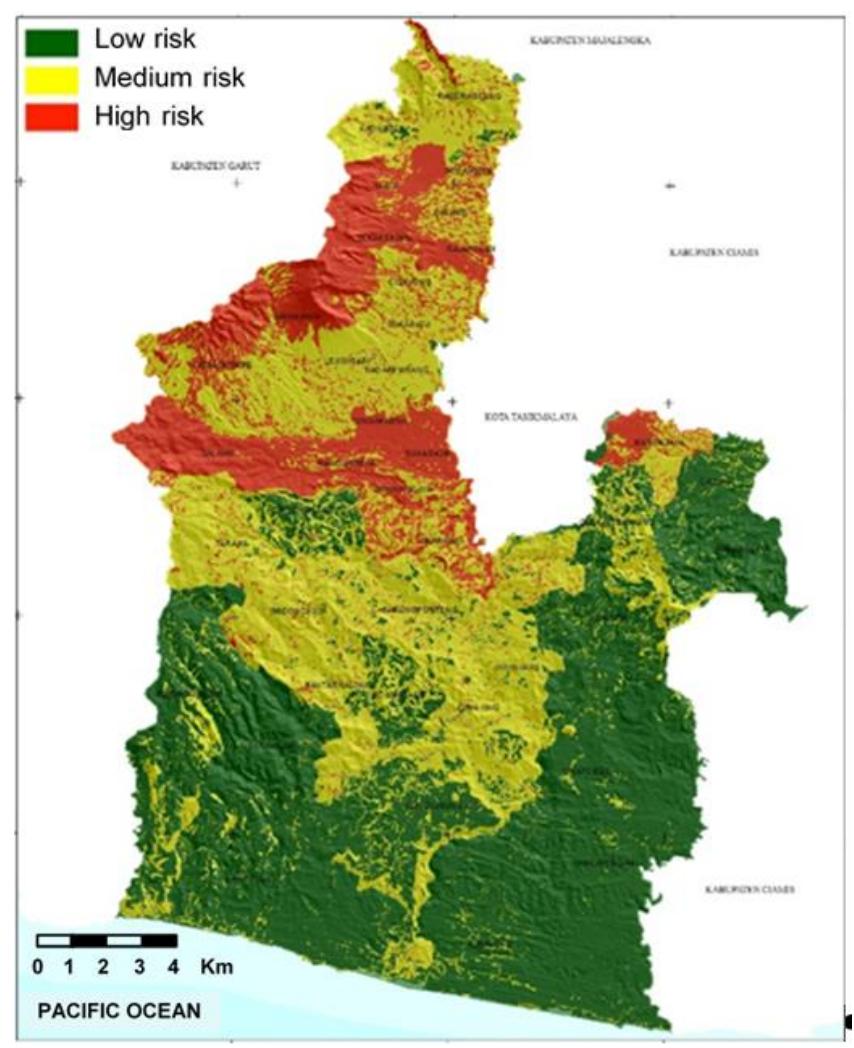

Figure 13. Map of earthquake disaster risk

\subsection{Multi-disaster Risk Mapping and Analysis}

Multi-disaster risk map was generated based on the sum of risk indexes of each threat based on the weight factors of each disaster. The result of overlay analysis from each disaster risk map was classified, according to BNPB Chief Regulation No. 02 Year 2012, into three multi-disaster risk classes which are: low risk $(60.08 \%)$, medium risk $(31.81 \%)$, and high risk $(8.10 \%)$. While the index values of threat type in the multi-disaster risk mapping according to BNPB Chief Regulation based on each threat were as shown below:

Table 2. Modified BNPB Chief Regulation No.02 Year 2012

\begin{tabular}{lll}
\hline No & Threat type & Percentage $(\%)$ \\
\hline 1 & Landslide & 40 \\
2 & Flood & 30 \\
2 & Earthquake & 30 \\
\hline
\end{tabular}

The overlay analyses from each multi-disaster risk map were classified, according to BNPB Chief Regulation No. 02 Year 2012, into three multi-disaster risk class with the Natural Breaks (Jenks) method, which are: low risk class $(57.01 \%)$, medium risk class $(35.08 \%)$, and high risk class $(7.92 \%)$. More details on the multidisaster risk distribution are shown in Figure 14 and Figure 15 for the tabulated and spatial format, respectively.

\subsection{Spatial Planning Study}

The Land Use Plan of (Rencana Tata Ruang Wilayah $R T R W)$ Tasikmalaya Regency which was regulated through Local Regulation No.2 Year 2012, was policy direction and strategy for spatial use in Tasikmalaya Regency area. The area space of Tasikmalaya Regency is a vessel that consists of land space, sea space, airspace, and also the space inside the earth, as a place for the Tasikmalaya Regency community to conduct activities and maintain their survival, as well as a resource that its management needs to be improved wisely. According to Local Regulation No.2 Year 2012 on Land Use Plan of Tasikmalaya Regency, the spatial area pattern plan of Tasikmalaya Regency consisted of cultivation area and protection area.

\subsection{Spatial Planning Study}

The Land Use Plan of (Rencana Tata Ruang Wilayah $R T R W)$ Tasikmalaya Regency which was regulated through Local Regulation No.2 Year 2012, was policy direction and strategy for spatial use in Tasikmalaya Regency area. 


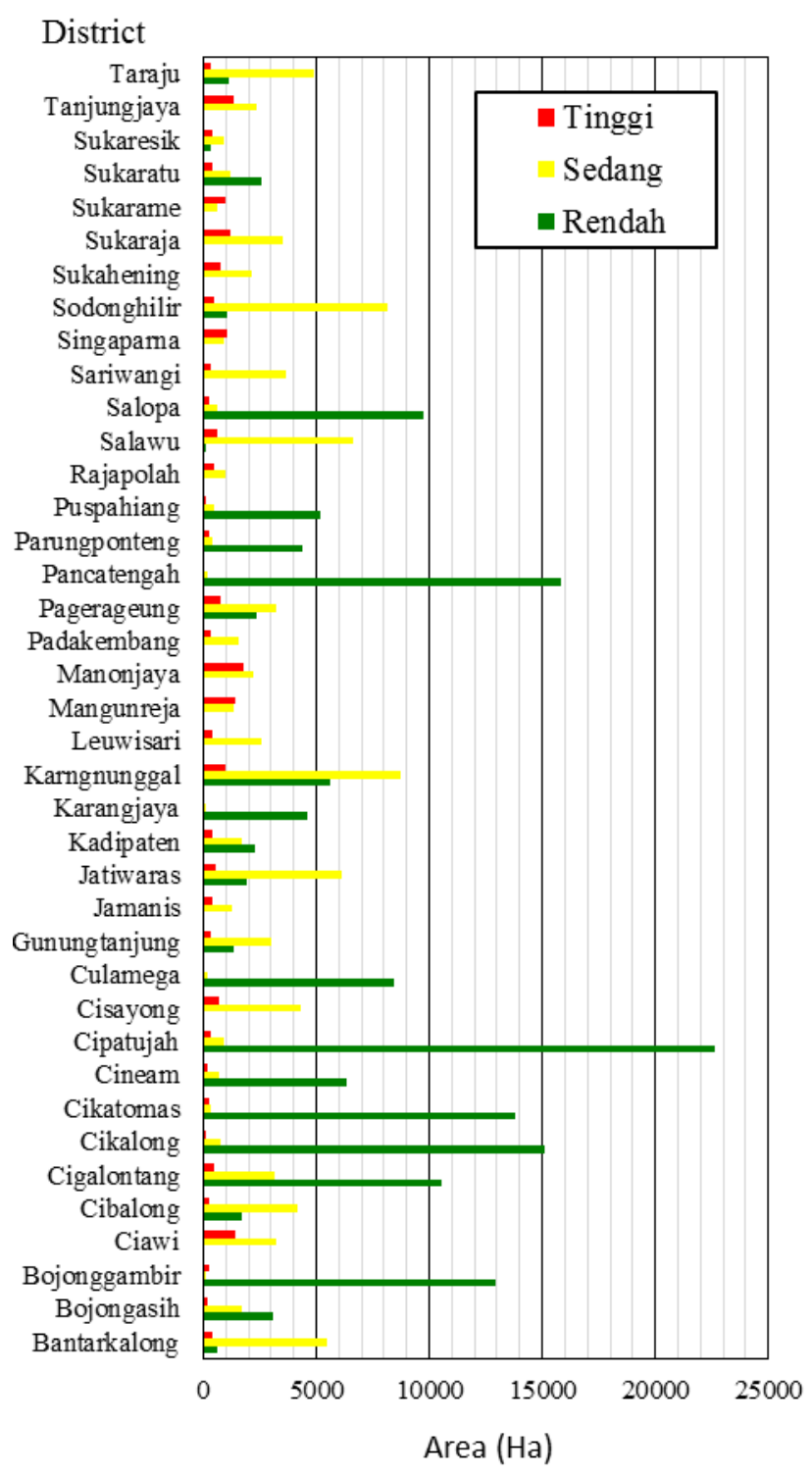

Figure 14. District-based disaster risk distribution

The area space of Tasikmalaya Regency is a vessel that consists of land space, sea space, airspace, and also the space inside the earth, as a place for the Tasikmalaya Regency community to conduct activities and maintain their survival, as well as a resource that its management needs to be improved wisely. According to Local Regulation No.2 Year 2012 on Land Use Plan of Tasikmalaya Regency, the spatial area pattern plan of Tasikmalaya Regency consisted of cultivation area and protection area.

According to Local Regulation No.2 Year 2012 on Land Use Plan of Tasikmalaya Regency, the areas that are included in the disaster-prone area spatial pattern, as referred in Article 35 that disaster-prone area are consisted of:

a) Earthquake prone area;

b) Volcanic prone area; and

c) Tsunami prone area.

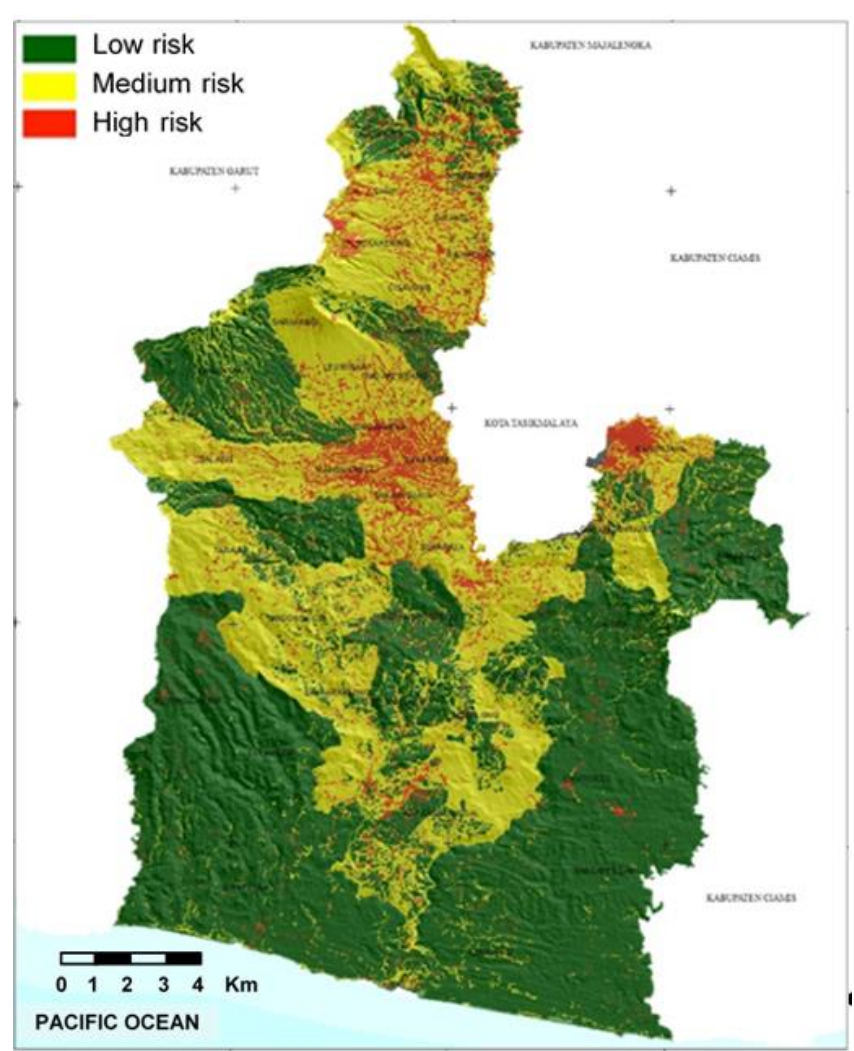

Figure 15. Map of multi disaster risk distribution

Based on Local Regulation No.2 Year 2012 on Tasikmalaya Regency Land Use Plan, the natural disaster-prone area (appendix 2), as in the Law No. 24 Year 2007 on Disaster Mitigation (Ministry of Public Works and Housing, 2007), is a geology, biology, hydrology, climatology, geographical, social, cultural, political, economic, and technological condition or characteristic of a certain area on certain period of time that reduces the ability to prevent, mitigate, achieve preparation, and reduce the ability to response to the adverse effect of certain hazard. One of the causal factors of disaster is environment. Therefore, the condition of disaster-prone area must be identified and spatial plan of disaster-prone area must be created. According to Government Regulation Number 26 Year 2008 on National Land Use Plan (Central Government of Republic Indonesia, 2008), the natural disaster area is divided into landslide prone area, tidal wave prone area, and flood prone area.

\section{CONCLUSION AND RECOMMENDATION}

\subsection{Conclusion}

Based on the data processing result from each parameter that affected the susceptibility level to disaster, the landslide, earthquake, and flood disaster susceptibility were obtained, the summaries are as follow: 
Based on the analysis result of landslide disaster susceptibility mapping which generated from the overlay of the parameters, the percentage of susceptibility class of landslide disaster were classified into 3 (three) classes as follows: low susceptibility $(18.86 \%)$, medium susceptibility $(45.44 \%)$, and high susceptibility $(35.70 \%)$. The slope parameter was the most influential parameter in determining the landslide susceptibility. This was because the larger slope value, the more it is vulnerable to the landslide. The driving force of soil/rock masses that build the slope would be higher, due to the amount of the driving force of soil/rock masses that build the slope. Another parameter was the geological formation because rock is the base of soil, which would influence the stability of the land above it. In addition, the rainfall intensity has a quite important role in the landslide process, compared to other parameters. The rainfall intensity was closely related with the soil saturation by rain, which could increase the mass that the soil must retain, until at the certain point where the soil could no longer hold the soil mass, and slide along its slip surface. The area that was included in the high susceptibility area was the area with rainfall $>2500 \mathrm{~mm} /$ year.

The susceptibility factor for flood disaster in this research consisted of 4 (four) parameters as follows, i.e. topography, geological formation permeability on the location, Roughness level - land cover, and vegetation

Based on the score and weight from each flood disaster parameters, the percentage was classified into 3 (three) susceptibility class, which are: low susceptibility class $(36.11 \%)$, medium susceptibility class $(47.81 \%)$, and high susceptibility class (16.07\%).

Earthquake susceptibility map was obtained from several parameters that affected the susceptibility level to earthquake disaster, such as geological data, data of distance from fault, earthquake intensity data, and data on value of spectral response acceleration of 0.2 seconds (Ss) which being exceeded in 50 years, at the Tasikmalaya Regency. From the data processing with ArcMap 10.3 software the percentage was classified into three classes as follows: low susceptibility $(9.40 \%)$, medium susceptibility (48.84\%), and high susceptibility $(41.76 \%)$.

Susceptibility is related to human activities, infrastructure, housing, etc. These factors were the major parts that needed to be considered in analyzing and determining this disaster risk. The landslide and flood disaster susceptibility level were classified into 3 (three) classes, which are: $40.95 \%$ low susceptibility class, $41.67 \%$ medium susceptibility class, and $17.39 \%$ high susceptibility class. The susceptibility for earthquake was classified into 3 (three) classes, which are: $42.66 \%$ low susceptibility class, $42.97 \%$ medium susceptibility class, and $14.39 \%$ high susceptibility class.

Capacity shows the tenacity level of a certain area to disaster. The capacity of an area affects the disaster risk level of an area. The higher the capacity of an area, the lower the disaster risk of the area will be. Overall, the capacity that the Tasikmalaya Regency has was still low.

Multi-disaster risk map is a study on disaster risk which basically determines the quantities of three risk components and presenting it into spatial or non-spatial form for easy understanding. The result of multidisaster risk map analysis was classified into 3 (three) classes, in accordance to the BNPB Chief Regulation No. 02 Year 2012: low risk criteria class $(60.08 \%)$, medium risk criteria class (31.81\%), and high risk criteria class $(8.10 \%)$. The area with high risk was mostly area with slope of $>15^{\circ}$ and elevation above $1000 \mathrm{~m}$ asl. Sub-districts that have high risk to landslide, flood, and earthquake disaster were: Mangunreja, Ciawi, Jamanis, Manonjaya, Rajapolah. Singaparna. Sukahening. Sukaraja. Sukarame, Sukaresik, and Tanjungjaya.

Risk study on landslide, flood, and earthquake disaster could be input and information material for arranging the spatial pattern planning in Tasikmalaya Regency. This is because, between the policies of spatial pattern that is being set as cultivation area, there is still area that has high risk of disaster.

\subsection{Recommendation}

Based on the process, result, and result analysis in this research, author could give recommendation and suggestion as follows.

a) Result of susceptibility map, susceptibility map, capacity map, and risk map are dynamic.

b) Result of susceptibility map, susceptibility map, capacity map, and risk map are very affected by parameters, therefore a more detailed research on influences of each parameter is needed.

c) Inadequacy in giving the weight and score quantity would generate an inexact map, and could even lead to disaster.

d) The weighting and scoring could not be applied generally in the entire region, for each region has differences in geological characteristic, soil type, land use, climate, etc.

e) On the arrangement of regional spatial planning (province/regency/city), the multi-disaster risk/susceptibility/susceptibility become the basic 
material in planning the land use that would calculate the disaster risk.

\section{REFERENCES}

Badan Nasional Penanggulangan Bencana (BNPB), 2012. Peraturan Kepala BNPB No 2 Tahun 2012 tentang Pedoman Umum Pengkajian Risiko Bencana, Jakarta.. Badan Nasional Penanggulangan Bencana (BNPB).

Central Government of Republic Indonesia, 2008. Government Regulation Number 26 Year 2008 on National Land Use Plan. Central Government of Republic Indonesia.

Dalezios, N. F., 2002. Environmental Remote Sensing. Volos: University Teaching, University of Thessaly.

e-EcoRisk, 2004. District business website support system and decision-making to address the environmental risk and disaster management of largescale industrial waste, Austin: Watershed and Stream Network Delineation, Center for Research in Water Resources, University of Texas.
FEMA P-154, 2015. Rapid Visual Screening of Buildings for Potential Seismic Hazard: A Handbook Third Edition. Washington, DC: FEMA.

Kafira, V., Albanakis, K. \& Oikonomidis, D., 2015. Flood Susceptibility Assessment using G.I.S. An example from Kassandra Peninsula, Halkidiki, Greece. Thessaloniki, Faculty of Sciences, Department of Physical and Environmental Geography.

Ministry of Public Works and Housing, 2007. Law of Minister No.24 Year 2007 on Guide of Regional Planning for Landslide Prone Area. Ministry of Public Works and Housing.

Ramadhanti, P., 2011. Kerentanan Wilayah Terhadap Gempa Bumi di Tasikmalaya [Earthquake Prone Area in Tasikmalaya]. Depok: University of Indonesia.

Soulios, G. C., 1996. General Hydrogeology (In Greek). Thessaloniki: Aristotle University of Thessaloniki, University Studio Press. 
[this page is intentionally left blank] 